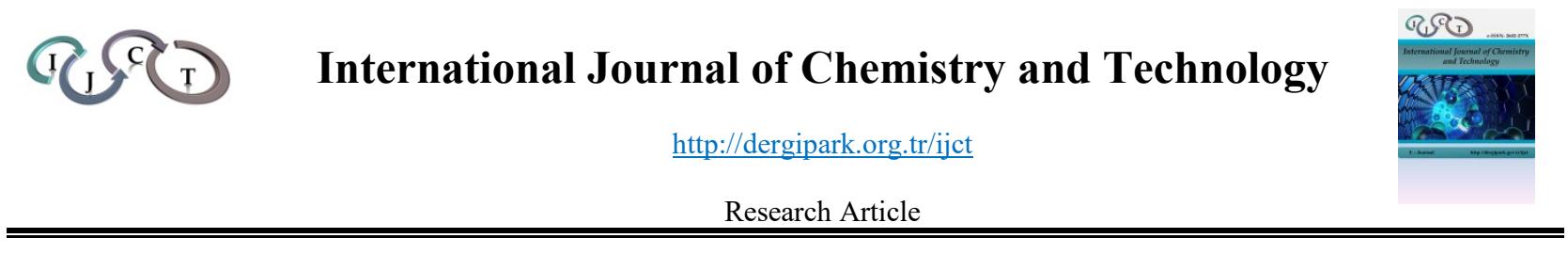

\title{
Comparison of the chemical composition and bioactive properties of extracts prepared from the mature Turkish and Brazilian banana peels
}

\author{
Tevfik ÖZEN1,*, (1) İbrahim DEMIRTAŞ²
}

\author{
${ }^{1}$ Department of Chemistry, Faculty of Arts and Sciences, Ondokuz Mayis University, 55139, Samsun, Turkey \\ ${ }^{2}$ Department of Chemistry, Faculty of Arts and Sciences, Igdir University, 76000, Igdir, Turkey
}

Received: 13 May 2021; Revised: 13 June 2021; Accepted: 13 June 2021

*Corresponding author e-mail: tevfikoz@omu.edu.tr

Citation: Özen, T.; Demirtaş, İ. Int. J. Chem. Technol. 2021, 5 (1), 67-76.

\begin{abstract}
The banana (Musa sp.) plant grows in tropical and subtropical regions. The fruit of the banana is eaten and the peel of the banana is discarded. In this study, chemical analyzes (HPLCTOF/MS ve GC-MS) and biochemical activities (antioxidant and antimicrobial) of ethyl acetate (Ea) and methanol/chloroform $(\mathrm{Me} / \mathrm{Ch})$ extracts prepared from banana peel (Bbp) grown in Brazil and banana peel (Tbp) grown in Turkey were investigated. Cetene, 4-hydroxybenzoic, palmitic, linoleic, stearic, gentisic and syringic acid are the most abundant compounds in the extracts. The total antioxidant activity of Tbp-Ea $\left(\mathrm{A}_{0.5}: 36.84 \mu \mathrm{g} / \mathrm{mL}\right)$, inhibition of lipid peroxidation of $\mathrm{Bbp}-\mathrm{Ea}\left(\mathrm{IC}_{50}: 3.22 \mu \mathrm{g} / \mathrm{mL}\right)$, reducing power of $\mathrm{Tbp}-\mathrm{Me} / \mathrm{Ch}\left(\mathrm{A}_{0.5}: 4.96 \mu \mathrm{g} / \mathrm{mL}\right)$, DPPH' scavenging activity of Bbp-Ea (IC50: $8.54 \mu \mathrm{g} / \mathrm{mL}$ ), metal chelating activity of Tbp-Ea (IC50: $16.54 \mu \mathrm{g} / \mathrm{mL}$ ) and $\mathrm{H}_{2} \mathrm{O}_{2}$ scavenging activity of Tbp$\mathrm{Me} / \mathrm{Ch}\left(\mathrm{IC}_{50}: 0.36 \mu \mathrm{g} / \mathrm{mL}\right.$ ) were found the most effective. It was exhibited that extracts were effective against gramnegative and gram-positive bacteria. In conclusion, the phytochemical and biochemical results of the TbP and Bbp extracts will contribute further pharmacological, biochemical and pharmacological investigations.
\end{abstract}

Key Words: Banana (Musa sp.) peel extract, polyphenolics, fatty acids, volatile compounds, bioactivity.

\section{INTRODUCTION}

Polyphenolics are the most common secondary metabolites in plants and contain at least one aromatic ring. Phenolics form different chemical structures with the hydroxyl group of carbohydrates, lipids, organic acids, amines and cell wall components. Due to their natural antimicrobial and antioxidant bioavailability,
Olgun Türk ve Brezilya muz kabuklarından hazırlanan ekstraktların kimyasal bileşimi ve biyoaktivite özelliklerinin karşılaştırılması

ÖZ

Muz (Musa sp.) bitkisi tropikal ve subtropikal bölgelerde yetişir. Muzun meyvesi yenir ve kabuğu atılır. Bu çalışmada Brezilya' da yetişen muz kabuğu (Bbp) ve Türkiye' de yetişen muz kabuğundan (Tbp) hazırlanan etil asetat (Ea) ve metanol/kloroform $(\mathrm{Me} / \mathrm{Ch})$ ekstraktlarının kimyasal analizleri (HPLC-TOF/MS ve GC-MS) ve biyokimyasal aktiviteleri (antioksidan ve antimikrobiyal) araştırıldı. Seten, 4hidroksibenzoik, palmitik, linoleik, stearik, gentisik ve siringik asit ekstraktlarda en bol bulunan bileşiklerdir. Tbp-Ea'nın toplam antioksidan aktivitesi (A $0.5: 36.84 \mu \mathrm{g} / \mathrm{mL})$, Bbp-Ea'nın lipid peroksidasyonunun inhibisyonu (IC $50: 3.22 \mu \mathrm{g} / \mathrm{mL}$ ), Tbp$\mathrm{Me} / \mathrm{Ch}^{\prime}$ in gücünü azaltma $\left(\mathrm{A}_{0.5}: 4.96 \mu \mathrm{g} / \mathrm{mL}\right)$, Bbp-Ea'nın $\mathrm{DPPH}^{\bullet}$ temizleme aktivitesi ( $\mathrm{IC}_{50}: 8.54 \mu \mathrm{g} / \mathrm{mL}$ ), Tbp-Ea'nın metal şelatlama aktivitesi ( IC $_{50}: 16.54 \mu \mathrm{g} / \mathrm{mL}$ ) ve Tbp$\mathrm{Me} / \mathrm{Ch}^{\prime}$ nin $\mathrm{H}_{2} \mathrm{O}_{2}$ temizleme aktivitesi ( $\mathrm{IC}_{50}: 0.36 \mu \mathrm{g} / \mathrm{mL}$ ) en etkili bulundu. Ekstraktların gram negatif ve gram pozitif bakterilere karşı etkiliğini gösterdi. Sonuç olarak, TbP ve Bbp ekstraktlarının fitokimyasal ve biyokimyasal sonuçları daha ileri farmakolojik, biyokimyasal ve farmakolojik araştırmalara katkı sağlayacaktır.

Anahtar Kelimeler: Muz (Musa sp.) kabuğu ekstresi, polifenolikler, yağ asitleri, uçucu bileşikler, biyoaktivite.

phenolic compounds in polymeric formulations present a wide range of applications in the fields of food, health and biotechnology. Consumption of products with high polyphenolics sources can slow, prevent or completely reverse the development of neurological cancer and cardiovascular diseases. Research of high polyphenolic content plants with the reuse of industrial fruit and vegetable wastes has increased the interest of researchers 
in the processing of vegetables and fruits. ${ }^{1}$ Research on the reuse of industrial fruit and vegetable debris containing high polyphenols has increased the interest of researchers in the recovery of by-products obtained during the processing stages of fruits and vegetables. ${ }^{2}$ Banana (Musa sp.) is one of the most consumed fresh and processed tropical fruits in the world due to its high vitamin, mineral, nutritional value and also low cost. ${ }^{3}$ Bananas are freshly consumed or processed to dry fruit ice-cream, jam and nectar to prepare functional foods, while peels constituting approximately $38 \%$ of fruitweight are considered waste. ${ }^{4,5}$ It was recorded that the peels are a waste product containing high dietary fibre and polyphenolic, and also have a strong antioxidant feature ${ }^{6-8}$ Recently, scientists have been in a lot of work to improve the nutritional value of food products and to reveal the value of food waste products. ${ }^{9,10}$ Banana peels are large quantities annually, evidenced by household, market, restaurant and food processing waste. The disposal of banana peel is a major concern, but in recent research, it has been suggested that banana peel is a source of important bioactive compounds. ${ }^{11} 1$ ton dry banana peel is presented as a material balance for based on the valorization biorefinery and the results exhibit that protein $(432 \mathrm{~kg})$, citric acid $(170 \mathrm{~kg})$, ethanol $\left(325 \mathrm{~m}^{3}\right)$ and methane $\left(220 \mathrm{~m}^{3}\right)$ can be produced. ${ }^{12}$ Banana peel has been used in different industrial field trials of organic fertilizer and refining agent. Gusmavartati et al. (2015) compared the banana peel and other organic natural product wastes in terms of carbon and nitrogen contents and reached very high results $(\mathrm{C}, 37.99 \%$ and $\% \mathrm{~N}$, $1.37 \%$ ). In addition, in this study, they obtained a very high yield of organic fertilizer by mixing with banana shells, house market and restaurant wastes at certain ratios. ${ }^{13} \mathrm{Bp}$ was determined to be a good absorbent for $\mathrm{Cr}(\mathrm{VI})$ ions in industrial wastewater. ${ }^{14}$

The climatic and geographical conditions of Turkey are suitable for growing bananas in the microclimate areas of the Mediterranean and Aegean regions as an agricultural product, and greenhouse cultivation is carried out. Imported bananas are preferred due to the size, colour difference and short shelf life of the banana grown in Turkey. However, Turkish people are highly preferred and consumed in the domestic market. In the literature, there are researches on the use of banana peel in different application areas. Although there are limited studies in the literature about Turkish banana, there is no research on the peel of Turkish banana. Thus, by comparing the phytochemical and bioactivities of the domestic and imported banana peel extracts, the content and activity of the domestic banana peels were revealed. In this work chemical contents of the ethyl acetate (Ea) and $\mathrm{MeOH} / \mathrm{CHCl}_{3}(\mathrm{Me} / \mathrm{Ch})$ extracts of mature Turkish banana peel (Tbp) and mature Brazilian banana peel (Bbp) were analyzed with HPLC-TOF/MS and GC-MS, and their bioactivities were performed with antioxidant and antimicrobial tests.

\section{MATERIALS AND METHODS}

\subsection{Chemicals}

The ethyl acetate, methanol, chloroform, hexane are HPLC grade solvents and were purchased from Merck. Ammonium molybdate, sodium phosphate, $\mathrm{K}_{3} \mathrm{Fe}(\mathrm{CN})_{6}$, trichloroacetic acid, $\mathrm{K}_{2} \mathrm{HPO}_{4}, \quad \mathrm{KH}_{2} \mathrm{PO}_{4}, \quad \mathrm{NADH}$ (nicotinamide adenine dinucleotide), NBT (nitroblue tetrazolium), PMS (ferrozine meta sulphate), $\mathrm{FeCl}_{3}$ and DPPH· (2,2-diphenyl-1-picrylhydrazyl) were provided from Sigma. The other chemicals were purchased from local commercial sellers.

\subsection{Sample}

The mature Turkish ( $\mathrm{Tb}$ ) and Brazilian bananas $(\mathrm{Bb})$ were purchased from the market. They were peeled and then their peels were dried in a dry and dark place at room temperature.

\subsection{Extraction and phytochemical analysis}

The dried $\mathrm{Tb}$ and $\mathrm{Bb}$ peels were extracted at room temperature and macerated with $10 \mathrm{~g}$ of banana peel $\mathrm{MeOH} / \mathrm{CHCl}_{3}(1: 1)$ solvent mixture in a closed container and the dark. ${ }^{15}$ At the end of the extraction period, the remains were filtered. Solvents of the extracts were removed in a vacuum on a rotary evaporator. Quantitative analysis and phytochemical content experiments were carried out with these extracted extracts. For GC-MS analyzes, the derivatization of the alcohols in the form of methoxy was carried out. The dried banana peel was added with a sufficient amount of purified water and subjected to boiling. After boiling, the extract was filtered with ordinary filter paper. The solvent mixture $\mathrm{MeOH} / \mathrm{CHCl}_{3}(\mathrm{Me} / \mathrm{Ch})$ was added to the remaining waste from the filtrate and stored. Ethyl acetate $(\mathrm{Ea})$ was added to the water portion obtained from the filtrate. The solvent of the Ea phase was completely evaporated.

The phenolic components of extracts were quantitatively determined with Agilent brand 1260 Infinity HPLC model and using Zorbax SB-C18 (4.6 x 100 mm-3.5 $\mu \mathrm{m})$ column 6210 and Time of Flight LC/MS detector. ${ }^{16}$ The acetonitrile and ultrapure water with formic acid (1\%) were used as a mobile phase mixture.

The application program was applied with per flow rate $(0.6 \mathrm{~mL}$ per minute), total injection volume $(10 \mu \mathrm{L})$ and column temperature $\left(35^{\circ} \mathrm{C}\right)$. The program was carried out so that the pure solvent mixtures were passed through the column in the range of $0-1$ minute, $10 \% \mathrm{~B}, 1-20 \mathrm{~min}$, $50 \% \mathrm{~B}, 20-23 \mathrm{~min}$, and 23-30 min [A: Water; B: acetonitrile] according to the solvent application programs. 


\subsection{Antioxidant activity}

The activities of extracts were performed in vitro by six different methods ${ }^{17}$ and compared with BHT. A 0.5 $(\mu \mathrm{g} / \mathrm{mL})$ values were found as an effective concentration at which the absorbance (A) was 0.5 value for total antioxidant activity and reducing power of extracts. And also $\mathrm{IC}_{50}$ values $(\mu \mathrm{g} / \mathrm{mL})$ were performed with effective concentration scavenging $50 \%$ of radicals for lipid peroxidation, metal chelating, $\mathrm{H}_{2} \mathrm{O}_{2}$ and free radical scavenging activities of extracts.

\subsubsection{Total antioxidant activity by phosphomolybdate assay}

The activity of extracts has performed the test described in literature ${ }^{18}$ and based on the reduction of $\mathrm{Mo}^{+4} \rightarrow \mathrm{Mo}^{+5}$ by the antioxidants. The formation of green $\mathrm{PO}_{4}{ }^{-3} / \mathrm{Mo}^{+5}$ compounds monitored at acidic $\mathrm{pH}$. A $0.3 \mathrm{~mL}$ sample was added to ammonium molybdate, sulfuric acid and sodium phosphate, respectively. Subsequently, the mixture of reaction activity was incubated at $95^{\circ} \mathrm{C}$, and read absorbance at $695 \mathrm{~nm}$.

\subsubsection{Assay of reducing power}

The reducing power of extracts was evaluated by Oyaizu Method with slight modification. ${ }^{19}$ The extract was mixed with $0.20 \mathrm{M}$ phosphate buffer $(\mathrm{pH} \mathrm{6.6)}$ ) and $10 \mathrm{~g} / \mathrm{L}$ $\mathrm{K}_{3} \mathrm{Fe}(\mathrm{CN})_{6}$, respectively. After the incubation period at $50{ }^{\circ} \mathrm{C}, 10 \%$ TCA $(2.5 \mathrm{~mL})$ was added to the reaction mixture and centrifuged at $3000 \mathrm{x}$ g to obtain a clear solution. $2.5 \mathrm{~mL}$ of the reaction mixture was combined with $0.1 \% \mathrm{FeCl}_{3}$ and water and read at $700 \mathrm{~nm}$ between 3 and 5 min after initiation of the reaction. It is indicated that the increased absorbance of the reaction depending on concentration has an effective reducing in the reaction condition that the reducing capacity had increased.

\subsubsection{Assay of free radical scavenging activity}

The activities of the samples were performed according to the reference. ${ }^{20}$ The $1 \mathrm{mM}$ of DPPH solution was combined with a sample in the test tubes and incubated at room temperature for $30 \mathrm{~min}$. The absorbance of the rection mixture was monitored at $517 \mathrm{~nm}$.

\subsubsection{Assay of $\mathrm{H}_{2} \mathrm{O}_{2}$ scavenging activity}

The activity of the sample was evaluated according to ref. ${ }^{21}$ A $1 \mathrm{~mL}$ extract solution was added in a flask to 0.1 $\mathrm{mM} \mathrm{H}_{2} \mathrm{O}_{2}$ in phosphate buffer ( $\mathrm{pH}$ 7.4), ammonium molybdate, $\mathrm{H}_{2} \mathrm{SO}_{4}$ and $\mathrm{KI}$. The reaction mixture was titrated with $5 \mathrm{mM} \mathrm{Na}_{2} \mathrm{~S}_{2} \mathrm{O}_{3}$ until the yellow color was lighter and the volume was recorded.

\subsubsection{Assay of metal chelating activity}

The chelating activity was performed by inhibiting the formation of ferrozine- $\mathrm{Fe}^{2+}$ complex after adding of extract with $\mathrm{Fe}^{2+} \cdot{ }^{22}$ In the presence of sample, this complex is disrupted with sample-chelated complex. The rate of red colour reduction allows to measure level of the chelating activity. The chelating complex level of extract with $\mathrm{Fe}^{+2}$ was recorded at 562 . Briefly, the sample was combined with $0.05 \mathrm{~mL} \mathrm{FeCl}_{2}$. After adding $0.2 \mathrm{~mL}$ ferrozine, the reaction medium was incubated at room temperature and then the absorbance of the mixture was measured at $562 \mathrm{~nm}$.

\subsubsection{Inhibition assay of lipid peroxidation}

The assay was carried out using TBA method based on inhibition level of linoleic acid peroxidation according to the modification literature method. ${ }^{23}$ Briefly, the extract was combined with linoleic acid, $100 \mu \mathrm{M}$ phosphate buffer ( $\mathrm{pH} 7.4$ ) and $20 \mu \mathrm{M}$ ascorbic acid. The reaction of peroxidation was initiated by adding of $10 \mu \mathrm{M} \mathrm{FeSO}_{4}(0.1$ $\mathrm{mL}$ ) and incubated for $60 \mathrm{~min}$. The mixture was added to $10 \%$ TCA solution and kept in water bath $\left(95^{\circ} \mathrm{C}\right)$. After cooling at room temperature, butanol was mixed with the reaction medium and centrifuged at $4000 \times \mathrm{g}$. After removing the supernatant, the formation of TBA reactive substance was monitored at $532 \mathrm{~nm}$.

\subsection{Antimicrobial activity}

The activity of extracts was performed three gram negative bacteria (Psedomonas aeruginosa ATCC15442, Escherichia coli ATCC25922, Klebsiella pneumoniae ATCC 10031) and three-gram positive (Enterococcus faecalis ATCC29212, Bacillus cereus CCM99, Staphylococcus aureus ATCC25213) bacteria. The microorganisms were cultured in Biochemistry Research Laboratory (Ondokuz Mayis University, Department of Chemistry, Biochemistry Laboratuvary). ${ }^{24,25}$

The antibacterial activities of extracts were tested by disc diffusion. ${ }^{26}$ The different concentrations of extracts were prepared a range of 1024-0.5 $\mu \mathrm{g} / \mathrm{mL}$. For disc diffusion method, amoxcillin and tetracycline were used as a positive and solvent as negative control. ${ }^{27} 6 \mathrm{~mm}$ sterile discs were impregnated with $20 \mu \mathrm{L}$ of extract materials and then incubated on MHA (Mueller Hinton Agar) medium for $16-18$ hours at $37{ }^{\circ} \mathrm{C}$ on where $100 \mu \mathrm{L}$ of suspension containing $0.5 \mathrm{McF}$ arland of bacteria spread on agar. The activity was evaluated by measuring the apparent transparent inhibition zones around the discs in millimeters.

\section{Statistical Analysis}

The data were presented as the mean \pm standard deviation (S.D.). The results were analyzed by one-way ANOVA of variance followed by Duncan's test and considered to be significant with $p<0.05$ confidence level, statistically. 


\section{RESULTS AND DISCUSSION}

The amount of banana production in Turkey is increasing every year. In 2015, the banana production is 270500 tons. Bananas consumption has increased with the understanding of human health. This increase is not met by the climatic factors that limit banana breeding. Turkey has imported 235188 tonnes of bananas in 2013 to ensure that this deficiency. ${ }^{28}$

Dried banana peels were extracted with boiling water prior to extraction with organic solvents, which are an important part of the characterization of the phenolic contents, due to the solvent-free residue of the banana shell for different purposes.

The use of banana peel in different areas has been investigated in Turkey. ${ }^{29,30}$ The water-soluble part of aqueous Turkish banana peel (Tbp) and Brazilian banana peel (Bbp) extracts can be an important source of raw materials such as phenolic and flavonoids for different applications and can be evaluated in different areas.

\subsection{Chemical analysis}

The analysis of the volatile compound and fatty acid components in the Tbp-Ea, Tbp-Me/Ch, Bbp-Ea and Bbp-Me/Ch extracts were made by GS-MS (Figure 1-4) and results were listed in Table 1. The 13,27-cycloursan3-one $(74.23 \%), 12$-oleanen-3-yl acetate $(16.47 \%)$ and 9,19-cyclolanost-23-ene-3,25-diol $(6.29 \%)$ were found high volatile compound in Tbp-Ea extract. Cetene (3.39\%), 15-heptadecenal (9.49\%), 9-hexadecenol (9.74\%), 1-nonadecene $(6.12 \%)$ and 9,19 -cyclolanost23-ene-3,25-diol (3.66\%) were the abudant volatile components in Bpb extract. Palmitic acid methyl, linoleic acid methyl and stearic acid methyl esters were the most common fatty acids in the extracts of $\mathrm{Me} / \mathrm{Ch}$ and $\mathrm{Ea}$ in both banana samples, and their values ranged from 38.25 to $0.04 \%$. HPLC-TOF/MS chromatograms of Tbp and Bbp extracts were obtained for quantitative and qualitative analysis as seen in Figure 5.

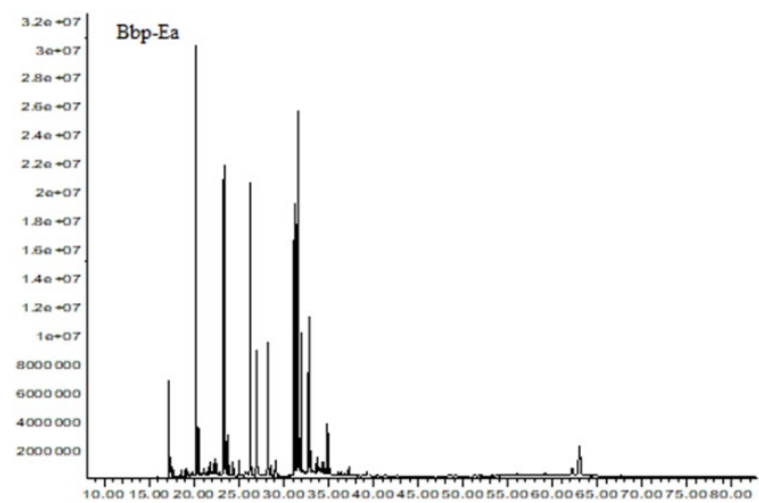

Figure 1. The GC analysis spectrum of Bbp-Ea extract

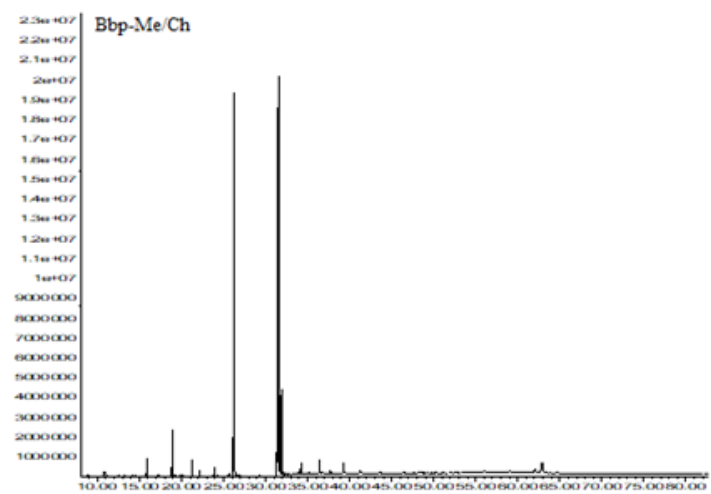

Figure 2. The $\mathrm{GC}$ analysis spectrum of $\mathrm{Bbp}-\mathrm{Me} / \mathrm{Ch}$ extract

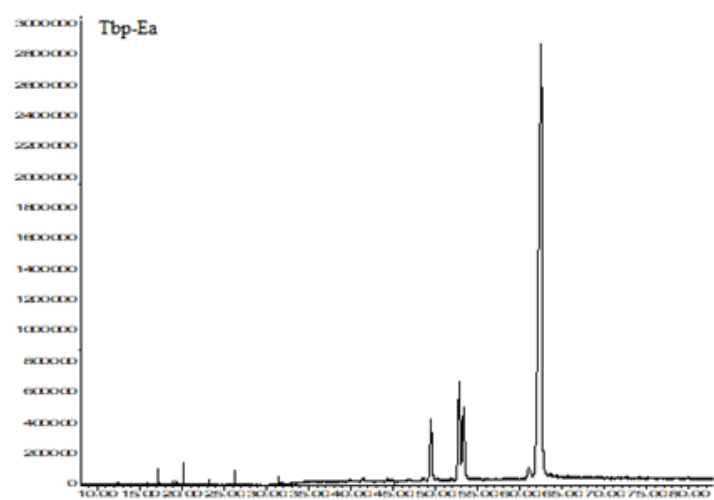

Figure 3. The GC analysis spectrum of Tbp-Ea extract

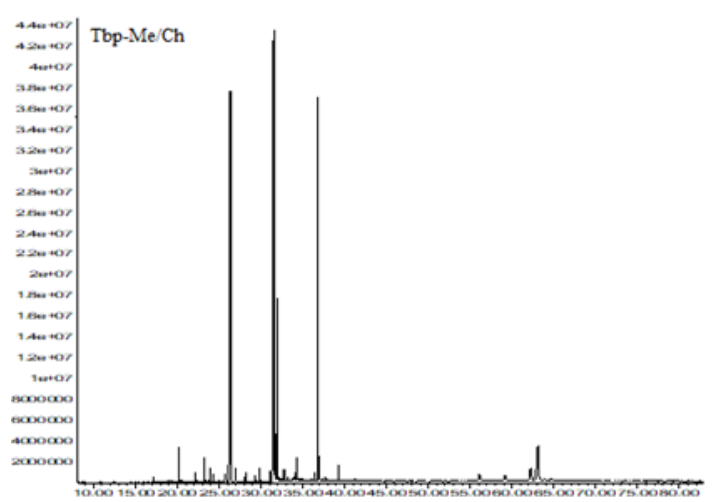

Figure 4. The GC analysis spectrum of Tbp-Me/Ch extract

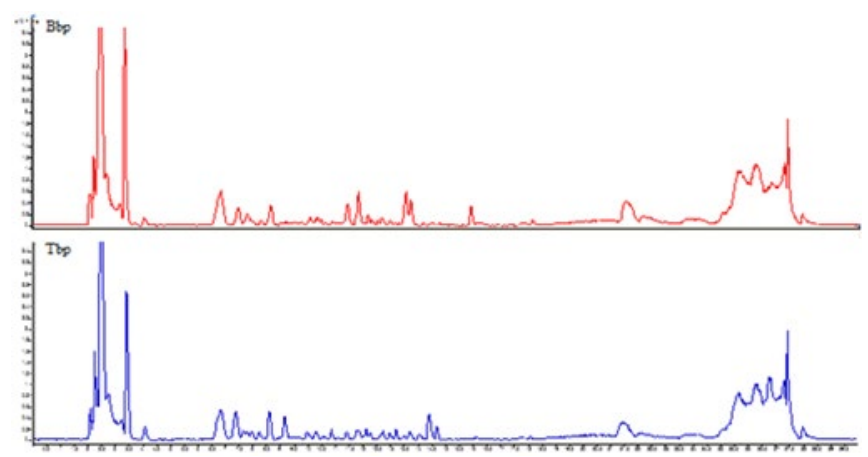

Figure 5. HPLC-TOF/MS chromatograms of extracts obtained from Bbp and Tbp 
Table 1. The volatile compounds and fatty acid components (\%) in the Tbp-Ea, Tbp-Me/Ch, Bbp-Ea and Bbp-Me/Ch extracts

\begin{tabular}{|c|c|c|c|c|c|c|}
\hline No & $\begin{array}{l}\text { Volatile } \\
\text { Compounds, \% }\end{array}$ & $\begin{array}{l}\mathrm{RT} \\
(\mathrm{min})\end{array}$ & $\begin{array}{l}\text { Bbp- } \\
\text { Ea }\end{array}$ & $\begin{array}{l}\text { Bbp- } \\
\mathrm{Me} / \mathrm{Ch}\end{array}$ & $\begin{array}{l}\text { Tbp- } \\
\text { Ea }\end{array}$ & $\begin{array}{l}\text { Tbp- } \\
\text { Me/Ch }\end{array}$ \\
\hline 1 & 1-Tetradecene & 17.180 & 3.33 & - & 0.35 & - \\
\hline 2 & 3-Tetradecene & 17.398 & 0.47 & - & - & - \\
\hline 3 & 7-Tetradecene & 17.591 & 0.42 & - & - & - \\
\hline 4 & 2,6-Di-tert-butylbenzoquinone & 18.598 & 0.22 & - & - & - \\
\hline 5 & Farnesane & 18.925 & 0.28 & - & - & - \\
\hline 6 & 2,4-di-tert-butyl- & 19.185 & 0.24 & - & - & - \\
\hline 7 & 2-Hexadecanol & 19.814 & 0.14 & - & - & - \\
\hline 8 & Cetene & 20.242 & 9.39 & - & 0.27 & 0.86 \\
\hline 9 & 1-Decanol 2-hexyl- & 20.318 & 0.35 & - & - & - \\
\hline 10 & 7-Hexadecene & 20.385 & 1.01 & - & - & - \\
\hline 11 & Benzophenone & 21.031 & 0.40 & - & - & - \\
\hline 12 & Methyl tridecyl phthalate & 21.492 & 0.14 & - & - & - \\
\hline 13 & 1,3-di-iso-propylnaphthalene & 21.643 & 0.20 & - & - & - \\
\hline 14 & 1,7-di-iso-propylnaphthalene & 21.727 & 0.36 & - & - & - \\
\hline 15 & Tetradecane & 21.819 & 0.20 & - & - & - \\
\hline 16 & 1-Hexadecanol & 21.995 & 0.11 & - & - & - \\
\hline 17 & 3-Eicosene & 23.262 & - & - & - & 0.78 \\
\hline 18 & 15-Heptadecenal & 23.312 & 9.49 & - & 0.09 & - \\
\hline 19 & 3-Octadecene & 23.489 & 0.90 & - & - & - \\
\hline 20 & 7-Octadecene & 23.757 & 1.00 & - & - & - \\
\hline 21 & Hexahydrofarnesyl acetone & 24.361 & 0.44 & - & - & 0.27 \\
\hline 22 & 18-Norabietane & 27.054 & 0.28 & - & - & - \\
\hline 23 & 1-Nonadecene & 28.228 & 6.12 & - & - & 0.59 \\
\hline 24 & 2-Methyl-7-nonadecene & 28.547 & 0.57 & - & - & - \\
\hline 25 & 5-Eicosene & 29.059 & 0.86 & - & - & - \\
\hline 26 & Methyl 2-ethylhexyl phthalate & 29.839 & - & - & - & 0.82 \\
\hline 27 & 1-Eicosanol & 31.147 & - & - & - & 0.61 \\
\hline 28 & 9-Hexadecenol & 31.173 & 9.74 & - & - & - \\
\hline 29 & Behenic alcohol & 32.775 & 2.93 & - & - & 0.39 \\
\hline 30 & Larixol & 32.934 & 0.20 & - & - & - \\
\hline 31 & 10-Heneicosene & 33.060 & 0.36 & - & - & - \\
\hline 32 & Methyl dehydroabietate & 34.587 & 0.16 & - & - & - \\
\hline 33 & 12-Oleanen-3-yl acetate & 52.798 & - & - & 16.47 & - \\
\hline 34 & Lupeol acetate & 53.335 & - & - & 8.01 & - \\
\hline 35 & Stigmasterol & 56.070 & - & - & - & 0.85 \\
\hline 36 & $\gamma$-Sitosterol & 59.157 & - & - & - & 0.69 \\
\hline 37 & 13,27 -Cycloursan-3-one & 62.169 & 0.97 & 0.73 & 74.23 & 1.98 \\
\hline 38 & 9,19-Cyclolanost-23-ene-3,25-diol & 63.007 & 3.66 & 3.18 & - & 6.29 \\
\hline No & Fatty acids & & & & & \\
\hline 1 & Undecanoic acid 10-methylmethyl ester & 19.303 & 0.22 & - & - & - \\
\hline 2 & Myristic acid methyl ester & 22.138 & 0.36 & 0.38 & - & 0.32 \\
\hline 3 & Pentadecanoic acid methyl ester & 23.916 & 0.28 & 0.73 & - & 0.50 \\
\hline 4 & Palmitoleic acid methyl ester & 25.670 & 0.27 & - & - & 0.52 \\
\hline 5 & Palmitic acid methyl ester & 26.282 & 11.77 & 38.25 & 0.36 & 30.63 \\
\hline 6 & $\begin{array}{l}\text { Benzenepropanoic acid } 3.5 \text {-bis } \\
\text { (1.1-dimethylethyl)-4-hydroxymethyl ester }\end{array}$ & 26.953 & 4.77 & - & - & 0.65 \\
\hline 7 & Margaric acid methyl ester & 29.327 & - & - & - & 0.41 \\
\hline 8 & Linoleic acid methyl ester & 31.407 & 6.87 & 18.81 & 0.19 & 23.13 \\
\hline 9 & Linolenic acid methyl ester & 31.550 & 11.83 & 30.77 & - & 22.27 \\
\hline 10 & Stearic acid methyl ester & 31.902 & 3.37 & 4.78 & 0.04 & 5.56 \\
\hline 11 & Arachidic acid methyl ester & 34.209 & 0.16 & 0.51 & - & 0.56 \\
\hline 12 & Behenic acid methyl ester & 36.424 & 0.12 & 0.87 & - & 0.31 \\
\hline 13 & Tricosanoic acid methyl ester & 37.732 & - & - & - & 0.16 \\
\hline 14 & Lignoceric acid methyl ester & 39.293 & 0.18 & 0.99 & - & 0.71 \\
\hline 15 & Pentacosanoic acid methyl ester & 41.163 & - & - & - & 0.14 \\
\hline
\end{tabular}

Bbp-Ea: Brazilian banana peel ethyl acetate extract

Bbp-Me/Ch: Brazilian banana peel methanol/chloroform extract

Tbp-Ea: Turkish banana peel aqueous extract

Tbp-Me/Ch: Turkish banana peel methanol/chloroform extract 
According to screening library and revealing retention time (RT) of calibration standards, 131 components in the Bbp (Bbp-EA, Bbp-Me/Ch) and 171 components in the Tbp (Tbp-AE, Tbp-Me/Ch) were found. As a standard, organic acids and phenolic components were used in the quantitative determination and 36 components were identified. From these components, 4hydroxybenzoic acid (Tbp-Ea: $68.41 \mathrm{mg}$, Tbp-Me/Ch: $50.26 \mathrm{mg}$ ), genestisic acid (Tbp-Ea: $0.47 \mathrm{mg}$, Tbp-
Me/Ch: $0.48 \mathrm{mg}$ ) and syringic acid (Tbp-Ea: $1.21 \mathrm{mg}$, Tbp-Me/Ch: $1.22 \mathrm{mg}$ ) were the most abundant in Tbp extracts (Table 2). The unknown compounds in Tbp and Bbp extracts were determined as seen in Figure 6 . Bismuth subgallate (Bbp), trimethobenzamide (Tbp), jasmonic acid (Bbp), 5b-cholestanol (Tbp) and rhein glucuronide $(\mathrm{Bbp})$ were the main unknown compound in extrats.

Table 2. Content analysis of organic acids and phenolic compounds in Tbp-Ea, Tbp-Me/Ch, Bbp-Ea and Bbp-Me/Ch extracts

\begin{tabular}{|c|c|c|c|c|c|}
\hline No & $\begin{array}{l}\text { Phenolics, } \\
\text { (mg phenolic/kg) }\end{array}$ & Bbp- Ea & Bbp-Me/Ch & Tbp-Ea & Tbp-Me/Ch \\
\hline 1 & Gallic acid & $\operatorname{tr}$ & $\operatorname{tr}$ & nd & nd \\
\hline 2 & 4-hydroxybenzoic acid & 0.57 & 1.37 & 68.41 & 50.26 \\
\hline 3 & Gentisic acid & 0.17 & 0.04 & 0.47 & 0.48 \\
\hline 4 & Protocatechuic acid & 0.06 & 0.09 & $\operatorname{tr}$ & nd \\
\hline 5 & Caffeic acid & 0.02 & $\operatorname{tr}$ & nd & $\operatorname{tr}$ \\
\hline 6 & Vanillic acid & 0.27 & 0.03 & 0.43 & nd \\
\hline 7 & Syringic acid & 0.07 & 0.10 & 1.21 & 1.22 \\
\hline 8 & Rutin & $\operatorname{tr}$ & 0.01 & 0.50 & 0.38 \\
\hline 9 & 4-hydroxybenzaldehyde & $\operatorname{tr}$ & $\operatorname{tr}$ & $\operatorname{tr}$ & $\operatorname{tr}$ \\
\hline 10 & Polydatine & $\operatorname{tr}$ & $\operatorname{tr}$ & $\operatorname{tr}$ & nd \\
\hline 11 & Ellagic acid & $\operatorname{tr}$ & nd & nd & nd \\
\hline 12 & Scutellarin & 0.04 & $\operatorname{tr}$ & $\operatorname{tr}$ & nd \\
\hline 13 & Quercetin-3- $\beta$-D-glucoside & 0.01 & $\operatorname{tr}$ & $\operatorname{tr}$ & $\operatorname{tr}$ \\
\hline 14 & Naringin & 0.01 & 0.04 & 0.02 & $\operatorname{tr}$ \\
\hline 15 & Diosmin & 0.18 & 0.20 & nd & 2.21 \\
\hline 16 & Taxifolin & 0.07 & $\operatorname{tr}$ & $\operatorname{tr}$ & nd \\
\hline 17 & Hesperidin & 0.03 & $\operatorname{tr}$ & $\operatorname{tr}$ & $\operatorname{tr}$ \\
\hline 18 & Apigetrin & $\operatorname{tr}$ & $\operatorname{tr}$ & nd & $\operatorname{tr}$ \\
\hline 19 & Neohesperidin & 0.20 & $\operatorname{tr}$ & nd & nd \\
\hline 20 & Myricetine & $\operatorname{tr}$ & $\operatorname{tr}$ & nd & $\operatorname{tr}$ \\
\hline 21 & Baicalin & $\operatorname{tr}$ & $\operatorname{tr}$ & nd & nd \\
\hline 22 & $p$-coumaric acid & $\operatorname{tr}$ & $\operatorname{tr}$ & $\operatorname{tr}$ & $\operatorname{tr}$ \\
\hline 23 & Fisetin & $\operatorname{tr}$ & $\operatorname{tr}$ & nd & nd \\
\hline 24 & Protocatechuic acid & $\operatorname{tr}$ & $\operatorname{tr}$ & $\operatorname{tr}$ & $\operatorname{tr}$ \\
\hline 25 & Morin & 0.03 & 0.06 & nd & nd \\
\hline 26 & Salicylic acid & $\operatorname{tr}$ & $\operatorname{tr}$ & $\operatorname{tr}$ & $\operatorname{tr}$ \\
\hline 27 & Quercetin & $\operatorname{tr}$ & $\operatorname{tr}$ & nd & nd \\
\hline 28 & Silibinin & $\operatorname{tr}$ & nd & $\operatorname{tr}$ & nd \\
\hline 29 & Cinnamic acid & 0.02 & nd & nd & nd \\
\hline 30 & Apigenin & 0.07 & $\operatorname{tr}$ & $\operatorname{tr}$ & $\operatorname{tr}$ \\
\hline 31 & Naringenin & 0.19 & $\operatorname{tr}$ & nd & nd \\
\hline 32 & Kaempferol & $\operatorname{tr}$ & nd & nd & nd \\
\hline 33 & Eupatorin & $\operatorname{tr}$ & nd & nd & nd \\
\hline 34 & Wogonin & 0.03 & nd & $\operatorname{tr}$ & $\operatorname{tr}$ \\
\hline 35 & Galangin & $\operatorname{tr}$ & nd & nd & nd \\
\hline 36 & Biochanin A & $\operatorname{tr}$ & nd & $\operatorname{tr}$ & $\operatorname{tr}$ \\
\hline
\end{tabular}

tr: tace; nd: not detected

Bbp-Ea: Brazilian banana peel ethyl acetate extract

Bbp-Me/Ch: Brazilian banana peel methanol/chloroform extract

Tbp-Ea: Turkish banana peel aqueous extract

Tbp-Me/Ch: Turkish banana peel methanol/chloroform extract 
<smiles>CC(O)c1cc(Cl)c2c(c1)OC(O)O2</smiles>

A

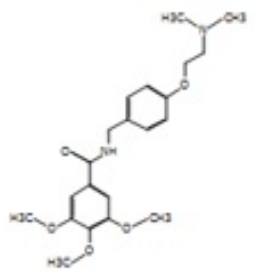

B

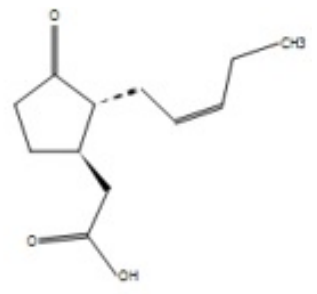

$\mathrm{C}$<smiles>CC(O)CCC[C@H](O)C1CCC2[C@@H]3CCC4CC(C)CCC4(C)C3CCC12O</smiles>

D

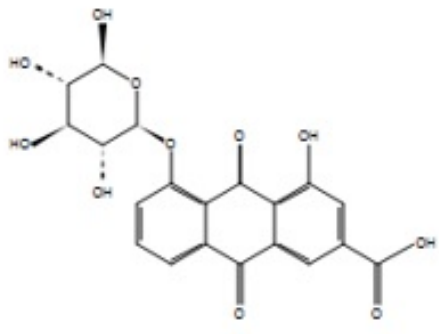

E

Figure 6. Unknown compounds from Bbp and Tbp extracts

\subsection{Antioxidant activity}

The antioxidant activities of Bbp-EA, Bbp-Me/Ch, TbpEA and $\mathrm{Tbp}-\mathrm{Me} / \mathrm{Ch}$ extracts were tested by total antioxidant activity, reducing power, inhibition of lipid peroxidation, metal chelating, free radical and $\mathrm{H}_{2} \mathrm{O}_{2}$ scavenging activity and compared with BHT and EDTA as positive controls (Table 3 ).

\subsubsection{Total antioxidant activity}

The activity was evaluated spectrophotometrically by phosphomolybdenum assay. In this assay, the extract reduced $\mathrm{Mo}(\mathrm{VI})$ to $\mathrm{Mo}(\mathrm{V})$ and the green-PO4-3/Mo+5 complex was formed. ${ }^{16}$ The activities of Bbp-Ea, Bbp$\mathrm{Me} / \mathrm{Ch}, \mathrm{Tbp}-\mathrm{EA}$ and $\mathrm{Tbp}-\mathrm{Me} / \mathrm{Ch}$ extracts and BHA showed a significant increase depending on concentration $(p<0.05)$. (Table 3). BHT, Tbp-Ea, Bbp$\mathrm{Me} / \mathrm{Ch}, \mathrm{Bbp}-\mathrm{Ea}$ and $\mathrm{Tbp}-\mathrm{Me} / \mathrm{Ch}$ showed the more effective $\mathrm{A}_{0.5}$ values, namely: $30.49,36.84,39.17,49.93$ and $71.45 \mu \mathrm{g} / \mathrm{mL}$. Tbp-Ea and Bbp-Me/Ch were good antioxidant sources and found to have high total antioxidant activity values which were correlated with their higher concentration of phenolics.

Table 3. Total antioxidant activity, reducing power, inhibition of lipid peroxidation, free radical scavenging and $\mathrm{H}_{2} \mathrm{O}_{2}$ scavenging activities of the Tbp-Ea, Tbp-Me/Ch, Bbp-Ea and Bbp-Me/Ch extracts

\begin{tabular}{|c|c|c|c|c|c|c|}
\hline \multirow[t]{2}{*}{ Sample } & $\begin{array}{c}\text { Total } \\
\text { antioxidant } \\
\text { activity }\end{array}$ & $\begin{array}{l}\text { Reducing } \\
\text { power }\end{array}$ & $\begin{array}{c}\mathrm{DPPH}^{\cdot} \\
\text { scavenging } \\
\text { activity }\end{array}$ & $\begin{array}{c}\text { Metal } \\
\text { chelating } \\
\text { activity }\end{array}$ & $\begin{array}{c}\mathrm{H}_{2} \mathrm{O}_{2} \\
\text { scavenging } \\
\text { activity }\end{array}$ & $\begin{array}{c}\text { Inhibition } \\
\text { of lipid } \\
\text { peroxidation }\end{array}$ \\
\hline & \multicolumn{2}{|c|}{$\mathrm{A}_{0.5}, \mu \mathrm{g} \mathrm{mL}^{-1}$} & \multicolumn{4}{|c|}{$\mathrm{IC}_{50}, \mu \mathrm{g} \mathrm{mL}-1$} \\
\hline Bbp-Ea & $49.93 \pm 3.07$ & $9.43 \pm 0.78$ & $10.50 \pm 2.73$ & $17.35 \pm 1.97$ & $0.71 \pm 0.15$ & $3.22 \pm 0.85$ \\
\hline Tbp-Ea & $36.84 \pm 2.57$ & $7.24 \pm 1.55$ & $21.63 \pm 1.53$ & $16.54 \pm 0.68$ & $0.81 \pm 0.09$ & $3.35 \pm 2.36$ \\
\hline Bbp-Me/Ch & $39.17 \pm 1.78$ & $4.96 \pm 0.95$ & $27.50 \pm 2.92$ & $19.70 \pm 1.62$ & $0.45 \pm 0.18$ & $12.38 \pm 3.43$ \\
\hline Tbp-Me/Ch & $71.45 \pm 4,19$ & $5.27 \pm 0.77$ & $25.31 \pm 1.75$ & $29.44 \pm 1.28$ & $0.36 \pm 0.11$ & $9.05 \pm 0.55$ \\
\hline BHT & $30.49 \pm 2.92$ & $4.02 \pm 0.28$ & $8.54 \pm 2.82$ & $4.77 \pm 0.97$ & $21.69 \pm 3.00$ & $2.14 \pm 0.73$ \\
\hline
\end{tabular}

The values were represented means $\pm \mathrm{SD}(n=3), p<0.05$

Bbp-Ea: Brazilian banana peel ethyl acetate extract

Bbp-Me/Ch: Brazilian banana peel methanol/chloroform extract

Tbp-Ea: Turkish banana peel ethyl acetate extract

Tbp-Me/Ch: Turkish banana peel methanol/chloroform extract

BHT: Buthylated hdroxytoluene

\subsubsection{Reducing power}

This assay is used to determine the electron donating capacity of an antioxidant. In the presence of a reductive polyphenol, $\mathrm{Fe}^{3+}$-ferricyanide leads to reduction of $\mathrm{Fe}^{2+}$ ferricyanide. Then, the color conversion is monitored spectrophotometrically. ${ }^{31} \mathrm{Bbp}-\mathrm{Ea}, \mathrm{Bbp}-\mathrm{Me} / \mathrm{Ch}$, Tbp-EA and $\mathrm{Tbp}-\mathrm{Me} / \mathrm{Ch}$ extracts exhibited effective reducing power at $700 \mathrm{~nm}$ (Table 3). It has been determined that the different concentrations of the extract are gradually increased with increasing concentration, but exhibit lower reduction power than BHA. The Tbp-Me/Ch extract showed reducing capacity higher than that of $\mathrm{Bbp}-\mathrm{Ea}, \mathrm{Bbp}-\mathrm{Me} / \mathrm{Ch}$ and Tbp-EA significantly. The reducing potential $\left(\mathrm{A}_{0.5}, \mu \mathrm{g} / \mathrm{mL}\right)$ of the extracts and standard increased in the following order: BHT, $4.02>$ 
Bbp-Me/Ch, $4.96>$ Tbp-Me/Ch, $5.27>$ Tbp-Ea, $7.24>$ Bbp-Ea, 9.43 .

\subsubsection{Free radical (DPPH) scavenging}

This assay was carried out with synthetic DPPH, which is widely used in antioxidant activity tests in evaluating the radical scavenging activity of natural and synthetic antioxidants. When an antioxidant and DPPH are mixed, the antioxidant gives an hydrogen to DPPH and the purple color turns into a yellow color. ${ }^{16}$ It was followed that the scavenging activities of $\mathrm{Bbp}-\mathrm{Ea}, \mathrm{Bbp}-\mathrm{Me} / \mathrm{Ch}$, Tbp-EA and Tbp-Me/Ch extracts and BHT were changed as the concentrations increased. Table 3 shows the DPPH scavenging capacities of the extracts. Extracts exhibited a lower free radical scavenging activity than BHT. Bbp-Ea and Tbp-Ea exhibited the effective $\mathrm{IC}_{50}$ values, namely: 10.50 and $21.63 \mu \mathrm{g} / \mathrm{mL}$.

\subsubsection{Metal chelating activity}

The $\mathrm{O}_{2}{ }^{-}$and $\mathrm{OH}$ radicals, which are the most active activators of oxidative stress, are of transition metal origin. These radicals transfer electrons, cause lipid peroxidation, damage proteins and accelerate lipid peroxidation. ${ }^{32}$ The antioxidant inhibits oxidation, reduce redox potential and stabilize the formation of metal oxide. Bbp-Ea, Bbp-Me/Ch, Tbp-EA and Tbp$\mathrm{Me} / \mathrm{Ch}$ extracts exhibited effective in stabilizing binding to the active transition metal as natural chelator products (Table 3). It was found that the extracts had lower effect on the formation of $\mathrm{Fe}^{2+}$-extract complex according to the formation of $\mathrm{Fe}^{2+}$-EDTA. The chelating activity of Tbp-
$\mathrm{Ea}\left(\mathrm{IC}_{50}: 16.54 \mu \mathrm{g} / \mathrm{mL}\right)$ was found close to Bbp-Ea $\left(\mathrm{IC}_{50}\right.$ : $17.35 \mu \mathrm{g} / \mathrm{mL})$.

\subsubsection{Inhibition of lipid peroxidation}

Oxidation products resulting from oxidation can permanently affect or modify the defence mechanism through different chemical and physical processes. Among the target substances of oxidation are DNA, oxygen, polyunsaturated fatty acids and phospholipids cholesterol. ${ }^{33}$ Lipid peroxidation is a radical chain process in which the primary products of lipid oxidation produced in the initial stage of the amount of peroxide and oxidation are measured. ${ }^{34}$ The Bbp-Ea, Bbp-Me/Ch, Tbp-EA and $\mathrm{Tbp}-\mathrm{Me} / \mathrm{Ch}$ affected by inhibition of linoleic peroxidation, $p<0.05$ and the results were exhibited in Table 3. The inhibition assays range from 10-100 $\mu \mathrm{g} \mathrm{mL}^{-1}$. The outcomes were expressed exclusively by Bbp-Ea $(3.22 \mu \mathrm{g} / \mathrm{mL})$ and Tbp-EA $(3.35$ $\mu \mathrm{g} / \mathrm{mL})$ exhibited a closer inhibition of linoleic peroxidation than that of BHT. Bbp-Ea and Tbp-Ea exhibited more effective inhibition of linoleic acid peroxidation $\left(\mathrm{IC}_{50}\right)$ than $\mathrm{Bbp}-\mathrm{Me} / \mathrm{Ch}$ and $\mathrm{Tbp}-\mathrm{Me} / \mathrm{Ch}$.

\subsection{Antimicrobial activity}

The activity results were exhibited in Table 4, where it can be seen that the Turkish banana peel extracts exhibited the best antibacterial activity against the $E$. coli, $E$. faecalis and K. pneumoniae tested in comparison with Brazilian banana peel extracts according to inhibition zone value.

Table 4. The antimicrobial activities of the Tbp-Ea, Tbp-Me/Ch, Bbp-Ea and Bbp-Me/Ch extracts

\begin{tabular}{|c|c|c|c|c|}
\hline \multirow{2}{*}{$\begin{array}{l}\text { Samples/ } \\
\text { Antibiotics }\end{array}$} & \multirow{2}{*}{ Test } & \multicolumn{3}{|c|}{ Gram-negative bacteria } \\
\hline & & E. coli & P. aeruginosa & K. pneumoniae \\
\hline Tbp-Me/Ch & \multirow{7}{*}{$\begin{array}{l}\text { Inhibition } \\
\text { zone, mm }\end{array}$} & $10.8 \pm 1.13$ & $8.75 \pm 0.49$ & $12.15 \pm 4.03$ \\
\hline Tbp-Ea & & $9.7 \pm 0.99$ & $9.95 \pm 0.78$ & $8.50 \pm 2.12$ \\
\hline Bbp-Me/Ch & & $7.95 \pm 0.64$ & NA & $8.85 \pm 1.06$ \\
\hline Bbp-Ea & & $7.25 \pm 0.35$ & $11.0 \pm 0.0$ & $10.70 \pm 1.84$ \\
\hline Tetracycline & & $25.25 \pm 0.35$ & $15.65 \pm 2.05$ & $20.30 \pm 0.28$ \\
\hline Amoxicillin & & $25.35 \pm 1.91$ & NA & NA \\
\hline Control & & $6.0 \pm 0.0$ & $6.0 \pm 0.0$ & $6.0 \pm 0.0$ \\
\hline \multirow{2}{*}{$\begin{array}{l}\text { Samples/ } \\
\text { Antibiotics }\end{array}$} & \multirow{2}{*}{ Test } & \multicolumn{3}{|c|}{ Gram-positive bacteria } \\
\hline & & E. faecalis & B. cereus & S. aureus \\
\hline Tbp-Me/Ch & Inhibition zone, & $9.75 \pm 0.07$ & NA & $7.0 \pm 0.00$ \\
\hline Tbp-Ea & $\mathbf{m m}$ & $16.6 \pm 0.00$ & NA & $8.20 \pm 0.85$ \\
\hline Bbp-Me/Ch & & $8.70 \pm 042$ & NA & $11.25 \pm 2.33$ \\
\hline Bbp-Ea & & $8.00 \pm 0.57$ & NA & $8.4 \pm 0.14$ \\
\hline Tetracycline & & $17.90 \pm 0.90$ & $47.00 \pm 4.24$ & $20.40 \pm 0.57$ \\
\hline Amoxicillin & & $25.7 \pm 0.99$ & $34.75 \pm 3.89$ & $26.95 \pm 0.78$ \\
\hline Control & & $6.0 \pm 0.0$ & $6.0 \pm 0.0$ & $6.0 \pm 0.0$ \\
\hline
\end{tabular}

NA: no activity. The values were represented means $\pm \mathrm{SD}(n=3), p<0.05$

Bbp-Ea: Brazilian banana peel ethyl acetate extract

Bbp-Me/Ch: Brazilian banana peel methanol/chloroform extract

Tbp-Ea: Turkish banana peel ethyl acetate extract

Tbp-Me/Ch: Turkish banana peel methanol/chloroform extract 
The Tbp-Ea was most active against E. faecalis in comparison to all the microorganisms tested and exhibited a broad spectrum of antibacterial activity. Specifically, the ethyl acetate and methanol/chloroform extracts showed different levels of antibacterial activity against gram positive and negative bacteria. This is supported by a previous study on water $^{35}$, isopropyl alcohol ${ }^{36}$ and ethyl acetate ${ }^{37}$ extracts that exhibit close or greater activity against ethyl acetate and methanol/chloroform extracts against bacteria without cellular toxicity.

\section{CONCLUSIONS}

The agro-residues can be considered a valuable resource after recycling and reprocessing. The banana peel has a lot of antioxidant activity and can be a very cheap source of extracts rich in bioactive compounds. This study showed that it had important effects on the phenolic contents extracted by extraction with $\mathrm{Ea}$ and $\mathrm{Me} / \mathrm{Ch}$. Total antioxidant activities of Tbp-Ea and Bbp-Me/Ch were found to be close to BHT. Tbp-Ea, Bbp-Ea, Bbp$\mathrm{Me} / \mathrm{Ch}$ and $\mathrm{Tbp}-\mathrm{Me} / \mathrm{Ch}$ are promising natural additives that exhibit antibacterial, $\mathrm{H}_{2} \mathrm{O}_{2}$ scavenging activity and the capacity to inhibit lipid peroxidation. However, the metal chelate capacity of the extracts was low. This research has compared the phytochemical and bioactivity potentials of Brazilian banana peel extract and Turkish banana peel extracts by chromatographic and spectroscopic analysis, and also revealed promising results.

\section{ACKNOWLEDGEMENTS}

This work was supported by Project Management Office (BAP), Ondokuz Mayis University, Samsun for supporting this research with PYO.FEN.1904.19.006 and PYO.FEN.1904.20.002 project numbers. We are also thankful to Sarmed Marah for helping in the antibacterial activity, and also Fatih Gül for the HPLC-TOF/MS and GC-MS analyzes of the extracts

\section{Conflict of interests}

The authours declare that there is no a conflict of interest with any person, institute, company, etc.

\section{REFERENCES}

1. Pandey, K. B.; Rizvi, S. I. Oxid. Med. Cell. Longev. 2009 2: 270-278.

2. Ravindran, R.; Jaiswal, A. K. Trends Biotechnol. 2016 34: 58-69.

3. Mohapatra, D.; Mishra, S.; Sutar N. Indian J. Biochem. Bio. 2010, 69, 323-329.
4. Aurore, G.; Parfait, B.; Fahrasmane, L. Trends Food Sci. Tech. 2009, 20: 78-91.

5. González-Montelongo, R.; Lobo, M.G.; González, M. Food Chem. 2010 119: 1030-1039.

6. Pereira, A.; Maraschin, M. J. Ethnopharmacol. 2015, 160: $149-163$.

7. Darsini, D.; Maheshu, V.; Vishnupriya, M.; Sasikumar, J. Indian J. Biochem. Bio. 2012, 49, 124129.

8. Can-Cauich, C. A.; Sauri-Duch, E.; BetancurAncona, D.; Chel-Guerrero, L.; González-Aguilar, G. A.; Cuevas-Glory L.F.; Pérez-Pacheco E.; MooHuchin V.M. J. Funct. Food 2017, 37: 501-506.

9. Singh, R.; Singh, G.; Chauhan G, Trends Food Sci. Tech. 1996, 33: 355-357.

10. Elleuch, M.; Bedigian, D.; Roiseux, O.; Besbes, S.; Blecker, C.; Attia H., Food Chem. 2011, 124: 411421.

11. Agama-Acevedo, E.; Sañudo-Barajas, J.; Vélez De La Rocha, R.; González-Aguilar, G.; Bello-Perez, L.A, Cyta-J. Food, 2016, 14: 117-123.

12. Pathak, P. D.; Mandavgane, S. A.; Kulkarni, B. D. Rev. Chem. Eng. 2016, 32: 651-666.

13. Yusuf, M, Journal of Tropical Soils 2016, 20: 59-65.

14. Memon, J.R.; Memon, S.Q.; Bhanger, M.I.; El-Turki, A.; Hallam, K.R.; Allen, G.C. Colloid Surface B. 2009, 70: 232-237.

15. Koldaş, S.; Demirtas, I; Ozen, T.; Demirci, M. A.; Behçet, L. J. Sci. Food Agr. 2015, 95: 786-798.

16. Ozen, T.; Yenigun, S.; Altun, M.; Demirtas, I., Comb. Chem. High T. Scr. 2017, 20: 559-578.

17. Gulcin, İ. Arch. Toxicol. 2020, 94: 651-715.

18. Prieto, P.; Pineda, M.; Aguilar, M. Anal. Biochem. 1999, 269: 337-341.

19. Oyaizu, M. Japanese Journal of Nutrition 1986, 44: 307-315.

20. Blois, M. S., Nature 1958, 181, 1199-1200.

21.Zhao, G. R.; Xiang, Z. J.; Ye, T. X.; Yuan, Y. J.; Guo, Z.X. Food Chem. 2006, 99: 767-774.

22. Dinis, T. C.; Madeira, V. M.; Almeida, L.M. Arch. Biochem. Biophys. 1994, 315: 161-169. 
23. Choi C. W.; Kim S. C.; Plant Sci. 2002, 163: 11611168.

24. Hudzcki, J. Kirby-Bauer Disk Diffusion Susceptibility Test Protocol. 2009, 1-23.

25. Ozen,T.; Kizil, D.; Yenigun, S.; Cesur, H.; Turkekul, I. Int. J. Med. Mushrooms 2019, 21.

26. Reller, L. B.; Weinstein M.; Jorgensen J. H.; Ferraro M. J., Clin. Infect. Dis. 2009, 49: 1749-1755.

27. Ozen, T.; Bora, N.; Yenigun, S.; Korkmaz, H. Flavour. Frag. J. 2020, 35: 270-283.

28. Saridaş, M. A.; Kargi, S. P.; Bayiroğlu B. M.; Şeyma, Y. Yüzüncü Yll Üniversitesi Tarım Bilimleri Dergisi. 2017, 27: 370-377.

29. Topbaşl1, B.; Sevinçli, Y. Electronic Journal of Vocational Colleges 2017, 7(1), 47-53.

30. Ince, M.; Ince, O.; Asam, E.; Önal, A. Atom Spectrosc. 2017, 38: 142-148.
31. Bursal, E.; Köksal, E. Food Res. Int. 2011, 44: $2217-$ 2221.

32. Haber F.; Weiss, J. Naturwissenschaften, 1932, 20: 948-950.

33. Antoovich, M.; Prenzler, P.D.; Patsalides, .E; Mcdonal, S.; Robards, K., Analyst, 2002, 127: 183198

34. Frankl, E. N, Lipid Oxidation. Elsevier, 2014, 391.

35. Chabuk, Z; Al-Charrakh, A.H.; Hindi, N.K.K.; Hindi, S.K.K., Res. Gate. Pharm. Sci. 2013, 1: 73-75.

36. Kapadia, S. P.; Pudakalkatti P.S.; Shivanaikar S. Contemp.Clin. Dent. 2015, 6: 496-499.

37. Mokbl, M. S.; Hashinaga, F. Am. J. Biochem. Biotechn.2005, 1: 125-131. 